7. Mozghovoi, M. (2007). Formation and tendencies of the Ukrainian variety song development. Extended abstract of candidate's thesis Kyiv: Kiev. nat. University of Culture and Arts [in Ukrainian].

8. Nazaikynskyi E. (1988). Sound world of music. Moscow: Muzika. [in Ukrainian].

9. Paliichuk A. (2016). Noematic prerequisites of V. Ivasyuk's style thinking. Musical Arts and Culture: Scientific Bulletin of the Odessa National Music Academy. A.V. Unexpected: coll. sciences. articles. O.V. Sokol (Ed.). Odesa: Astroprynt, issue 23. pp. 269-279. [in Ukrainian].

10. Samoilenko, O. (2014). Modern musical language or the language of contemporary music: two theoretical paradigms of one artistic phenomenon. LAUDATIO. Anniversary Collection of Scientific Articles in Honor of Professor Yuriy Yasinovsky. U. Hrab, O. Kozarenko, N. Syrotynska (Eds.). Lviv: Vydavets Taras Tetiuk, 155-163. [in Ukrainian].

11. Cherednychenko, T. (1994). Music in the history of culture. Course of lectures: 2nd issue., One-volume. Moskva: Dolhoprudnii: Allehro-Press [in Russian]. Russian].

12. Eko, U. (1998). The missing structure. Introduction to semiology. St. Petersburg: TOO TK «Petropolys» [in

Стаття надійшла до редакції 09.07.2019 p.

UDC 748.5

Petrushevski Andrii
Candidate of Technical Sciences,
Associate Professor of Information Technologies,
University Infrastructure and technology
ORCID 0000-0002-4199-2179
andriypetrushevskyy@yahoo.com.ar
Petrushevska Natalia
ORCID. 0000-0001-5542-0174

\title{
BASIC STAGES OF THE ALGORITHM OF RECONSTRUCTION OF ANCIENT GREEK EASEL PAINTING IN THE CONTEXT OF MODERN TECHNOLOGICAL POSSIBILITIES
}

The purpose of the article. Based on available historical information to form an algorithm scheme of action that allows you to create a reconstruction of lost composition of easel painting outstanding masters of Ancient Greece. The methodology of the research is based on the application of historical, cultural, artistic, and biographical approaches. The research used methods of computer modeling and analysis that allowed improving the accuracy of the results. To carry out the reconstruction of a particular work, it is necessary to make an integral representation of such a phenomenon as ancient Greek easel painting, for which it is essential to consider its main aspects: origin, development, principles of classical painting, technology of encaustic painting, influence on other types of fine arts, (philosophy, practical use, subject matter). The scientific novelty is to create a scheme of actions which have the aim to restore the image as close as possible to the lost original. Conclusions. Depending on the available historical material, reconstruction of lost images of ancient greek easel painting with a greater or lesser degree of probability is possible. The proposed algorithm of the article allows for solving this problem. It is established the essential, necessary items for the restoration of the lost pictorial works of art. The primary reconstruction algorithm is described: the drawing, composition, and methodology of the work of ancient Greek art. Systematized Hellenistic Greek colors according to the scheme "Colored Square". A sequence has been developed for the reconstruction of the central figure of Apelles' work: "Aphrodite Anadiomena."

Key words: reconstruction, ancient greek easel painting, encaustic painting, kameo, drawing, composition, culture, artistic task.

Петрушевський Андрій Олександрович, кандидат технічних наук, доцент кафедри інфрормаційних технологій Державного університету інфраструктури; Петрушевська Наталія Ігоревна

Основні етапи реконструкції давньогрецького станкового живопису в контексті сучасних технологічних можливостей.

Мета роботи - на основі наявної історичної інформації сформувати алгоритм схеми дій який дозволяє створювати реконструкцію втрачених композицій станкового живопису видатних майстрів Стародавньої Греції. Методологія дослідження ґрунтується на застосуванні історичного, культурологічного, мистецтвознавчого і біографрічного підходів. У дослідженні були використані методи комп'ютерного моделювання та аналізу що дало можливість підвищити точність отриманих результатів. Для здійснуння реконструкції конкретного твору, необхідно скласти цілісне уявлення про основні аспекти: походження, розвиток, принципи класичного живопису, технологію енкаустики, вплив на інші види образотворчого мистецтва, (філософію, практичне використання, тематику). Наукова новизна полягає в створенні схеми дій спрямованих на відновлення зображення максимально наближеного до втраченого оригіналу. Висновки. Залежно від наявного історичного матеріалу можлива реконструкція втрачених зображень Давньогрецької станкового живопису з більшим чи меншим ступенем вірогідності. Запропонований в статті алгоритм дій дозволяє вирішити це завдання.

Ключові слова: реконструкція, давньогрецька станковий живопис, енкаустика, камея, малюнок, композиція, культура, художнє завдання.

(C) Petrushevski A., 2019

(C) Petrushevska N., 2019 
Петрушевский Андрей Александрович, кандидат технических наук, доцент кафедры информационных технологий Государственного университета инфраструктуры; Петрушевская Наталия Игоревна

Основные этапы реконструкции древнегреческой станковой живописи в контексте современных технологических возможностей.

Цель работы - на основе дошедшей исторической информации сформировать алгоритм схемы действий позволяющий производить реконструкцию утраченных композиций станковой живописи выдающихся мастеров Древней Греции. Методология исследования основывается на применении исторического, культурологического, искусствоведческого и биографического подходов. В исследовании были использованы методы компьютерного моделирования и анализа что дало возможность повысить точность полученных результатов. Для осуществления реконструкции конкретного произведения, необходимо рассмотреть основные аспекты: происхождение, развитие, принципы классической живописи, технологию энкаустики, влияние на другие виды изобразительного искусства, (философию, утилитарное применение, тематику). Научная новизна заключается в создании схемы действий направленных на восстановление изображения максимально приближенного к утраченному оригиналу. Выводы. В зависимости от имеющегося исторического материала возможна реконструкция утраченных изображений Древнегреческой станковой живописи с большей или меньшей степенью достоверности. Предложенный в статье алгоритм действий позволяет решить подобную задачу.

Ключевые слова: реконструкция, древнегреческая станковая живопись, энкаустика, камея, рисунок, композиция, культура, художественная задача.

The relevance of the research topic. In connection with the development of information technology, the issues of these studies acquire a practical application for creating specialized databases.

Formulation of the problem: To date, the problem of reconstruction is almost not covered in the modern scientific literature. Although all the necessary technical tools are already available, of course, this is a difficult job, but essential for a fuller understanding of the ancient past. In our opinion, the possibility of reconstructing of a drawing and composition is based on the traditions of the ancient Greeks, making countless copies of famous paintings in various techniques, because painting was valued above other types of art. Descriptions of contemporary poets and historians, copies which were made in different techniques, can help in searching for the composition of a lost pictorial original. Reliefs have particular value because they mostly adequately reflect the location of minor figures and details. The most noticeable reliefs in ancient Greek painting are cameos, which were not accidentally called "stone painting." Each known work was reproduced not only in copies but also in interpretations.

Analysis of recent research and publications: Unfortunately, skepticism about reconstruction exists in the modern scientific community. This explains the almost complete lack of publications on this topic. Of course, we cannot claim absolute conformity to the original; this, unfortunately, is impossible without the presence of the work itself. However, we can get as close as possible using the action algorithm described in this article. On this topic, we can meet comments in the work of the outstanding Russian specialist in ancient culture, O. Neverov. "Ancient cameos in the Hermitage collection, "where the author explicitly notes the possibility of using cameos for the reconstruction of classical works. In modern publications, this topic is missing.

The objective is based on the historical information that has come down, form an algorithm for the action scheme that allows for the reconstruction of lost compositions of easel painting by outstanding masters of ancient Greece.

The presentation of the main material. The classical European technique of painting is based on ancient Greek technology. This is an indisputable fact. Despite this, it still hides a lot of mysteries, and this is a white spot on the map of art history. Roman painting, which came to us from the cities of Pompei and Herculaneum buried under the ashes, is not an example of the glorified Greek art of the fourth century B.C., both in technological and artistic aspects. Pliny the Elder wrote in the 1st century A.D. that the once-great art of painting, in his time, was already fading away [3, 82], and no artist could restore Apelles' masterpiece Aphrodite Anadiomena. The masterpieces of Hellenistic Greek painting differed in hyperrealism due to the invention of Apollodorus: - modeling of shades, as well as thanks to the invention of Pavsias from Sicyon - layered painting, technique, which became the basis of European academic painting. Reconstruction of ancient Greek painting is the most important task of the modern school of art. Pliny identifies three stages of development of Greek painting, at the first of which was linear, at the second - monochrome, and at the third "more elaborate was invented, and such painting continues to exist even now." Even the name of the artist, Philokles from Egypt, who invented linear painting, according to Pliny, invented the unconditional influence of Egyptian traditions. The origin and development of ancient Greek painting proceeded in two centers: Sicyon and Corinth. It is these cities that are repeatedly mentioned in "Natural History" in connection with the invention of painting by the Greeks, the development of its linear appearance, the first use of paint "from pounded tiles" [3, 81]. Also, the author of "Natural History" makes the necessary clarification that "only those artists who painted pictures on boards" have fame $[3,118]$, which distinguishes easel painting as the main one in ancient Greek culture. Apollodorus invents light and shadow modeling (the last third of the V century B.C.). Pliny mentions two theorists of the art of Antigonus and Xenocrates, who left tracts on painting, which confirms the presence in $\mathrm{V}$ a. C. theory of painting. Greek epigrams that describe works of art and their creators, which demonstrate the highest skill of the artist. By combining a scientist and artist, Apelles was not only a master of realistic cut-and-shadow modeling of forms, but also a master of movement composition. He was famous for his painting "Aphrodite Anadiomena," depicting the goddess of love, emerging from the sea foam. 
The popularity of this work prompted other masters to reproduce it in sculpture, an example of which is a Roman copy, reached our days. It is also remarkable that not only aspects such as composition, drawing, technology, formal techniques, color harmony, but also the art of painting with varnish were important for the final quality of the painting. Pliny writes that there was no equal in this art to Apelles. [3, 97]. Innovation of Pavsias was the image of the object in a strong perspective, which indicates the highest skill of drawing. On the big picture "Bull sacrificing," "wanting to show the length of the bull, he wrote it in front, not on the side ..." $[3,104]$. The most remarkable invention of Pavsias was a fundamentally new method of creating a pictorial work, consisting in the layered principle of applying local color and light. Thus, Pavsias from Sicion can be considered the creator of the technology of classical painting. Thanks to the work of Pliny the Elder, we know the name of the first Roman master of monumental painting in the genre of landscape, Studio, "who lived during the divine Augustus." The studios were the first to paint not only the walls of interiors but also "walls in rooms in the open air." [3, 102] On the level of painting of its time, that is, I century A.D. Pliny reports that already "there is no famous painting." In the fairness of such an assessment can be seen by looking at the monumental painting of Pompey, where it is obvious that the school of drawing, painting and composition still existed, but the level of art has already been lost. Plinio reports that already "there is no famous painting." [3, 88] On the level of painting of its time, that is, I century A.D. It is necessary to say about the palette of colors used by the ancient Greeks to achieve incredible peaks of art, as evidenced by history. There were only four of these colors: white (Melos), ocher (Attic), red (Pontic Sinop) and black (atrament). The issue of reconstruction of the original technology of hot encaustic painting remains open until recently. The author of the book "Antique Cameos in the Hermitage Collection" and the compiler of the catalog O. Neverov wrote: "Of all aspects of studying ancient cameos, perhaps the most interesting and promising is the question of their relation to the antique easel painting." Layered sardonyx reproduced the layer-by-layer classical effect painting, and the translucency and color saturation of the stone resembled encaustic painting. "Along with the Pompeian frescoes, reliefs, and objects of toreutics, cameos are indispensable for the reconstruction of forever lost easel works of ancient painters. When the same composition without changes is repeated in a fresco, decorative relief, on a silver or bronze vessel, a lamp, and a cameo, it can be infallibly assumed that the basis of these repetitions is a picturesque original. Reconstruction of works of ancient Greek easel painting consists of such stages as:

1. Composition reconstruction;

2. Reconstruction of the picture;

3. Reconstruction of the system of painting.

The reconstruction of the composition consists of such stages as: niques;

1. The study of the surviving artifacts and the selection of the most repeated compositional tech-

2. Refinement of such elements of the composition as: a) board format; b) the height of the horizon line; c) minor figures and details.

The reconstruction of the drawing consists of such stages as:

1) Compilation of extant artifacts that coincide with the descriptions of ancient authors.

2) Reconstruction of the image based on the resulting image.

Reconstruction of painting consists of such stages as:

1) Definition of color solutions based on antique samples;

2) Creation of the project of layer-by-layer classical painting with fixation of all intermediate layers;

3) Performing encaustic painting on a wooden base. 


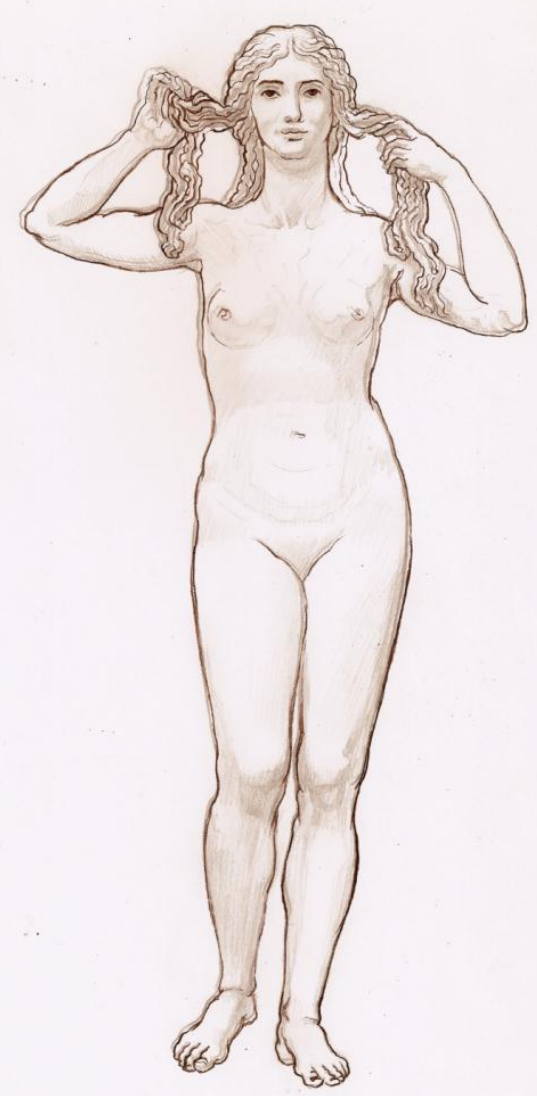

a. Drawing

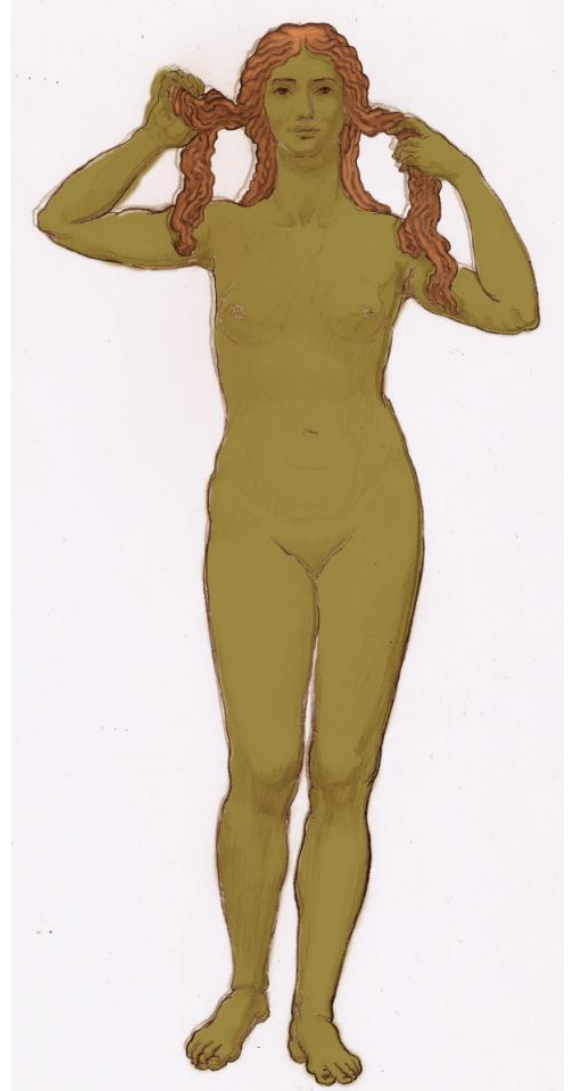

b. Middle tone

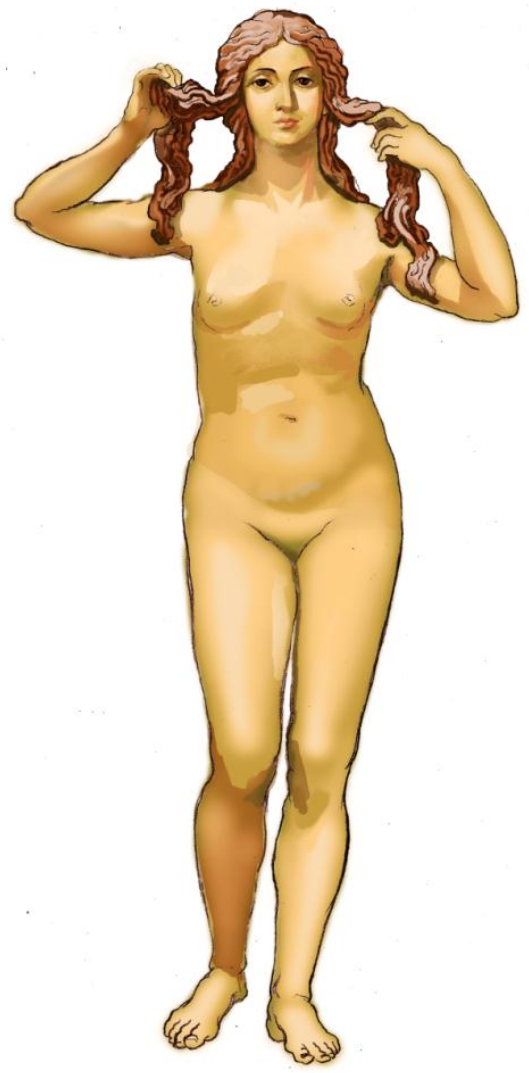

c. Volume model

Fig. 1. The scheme of the stages of work in the reconstruction of the figure of Aphrodite Apelles. (Developed by the authors).

As an example, we can cite the unusual work of Apelles: "Aphrodite Anadiomena." Here we see the methodology, which from our point of view allows us to restore the image of the goddess. We are practically convinced in the central figure. The most numerous descriptions, copies and interpretations refer to the image of Aphrodite Anadiomena. Two sculptural copies that correspond to the epigrams and the description of Pliny the Elder: "Aphrodite Cyrene", which returned to Libya in 2008, and "Aphrodite Anadiomena", located in the National Museum of Rome. E. Rothenberg wrote about the statue of Aphrodite of Cyrene: The statue depicted Aphrodite coming out of the water and compressing wet hair, as depicted in the famous painting of the great Greek artist Apelles." Unfortunately, the head and hands of the statue did not survive [6, 275]. The most informative copy is "Aphrodite Anadyomena" from the National Museum of Rome because she held not only her hands, but also her curled hair. The head of Aphrodite is preserved in the interpretation of "Aphrodite of Rhodes", as well as in the form of numerous statuettes. When refining the portrait of Aphrodite Anadomena by Apelles, one should pay attention to the Praxitele sculpture "Aphrodite Cnidus," which undoubtedly depicts the portrait of Phryne, who inspired Apelles and Praxiteles, famous friends, to create masterpieces, painting, and sculpture. It is known that Protogen wrote an essay in two volumes "On the art of painting and schemes" [3]. The academic school of drawing, composition, and color harmony, starting from its ancient origin, was based on schemes designed by outstanding artists and sculptors of ancient Greece. The "limited palette" of ancient Greek artists consisted of only four colors, which made it possible to create a harmonious, rich, and exquisite painting. We can systematize four colors (red, yellow, white, and black) in a square of colors (Fig. 2). Such a scheme of harmony of colors could be in Protogen's treatise. The square of colors (Fig. 2) of ancient Greek painting is a simple and clear scheme of the harmonious combination of the nuances of additional colors. Unlike the Goethe color wheel, which includes two spectral color triads without black, the Color Square (Fig. 2) contains the basic information necessary for classical painting, which cannot exist without black paint. A remarkable characteristic of the Square of Flowers (Fig. 2) is that the additional pairs of facial shades are already in a different tonal state, which is necessary for their harmonious combination. The transition from yellow to white and from red to black is carried out diagonally. Harmonious chords of contrasting color nuances are also found on the diagonal axes. The square of colors (fig.2) is intended for artists taking into account the specific requirements of classical painting and consists of 25 squares. Corner squares occupy primary colors. The black color of the Color Square (Fig. 2) is located in the lower right corner and performs the same function as the blue color of the Goethe Color Circle or Otto Runge Color Sphere, but with a quality result that is more harmonious for classical painting. Black paint mixed with white 
paint in various proportions gives blue-gray shades. Applying layers of white paint on a gray imprimatura gives a bluish tint. The white color is in the lower-left corner. The red color is in the upper left corner. The yellow color of the Flowers Square (fig.2) is in the upper right corner. Three transition tones connect each of the four colors with its neighbor. The transitional tones of complementary colors are conveniently located opposite each other along the vertical and horizontal axes. A remarkable characteristic of the Square of Flowers (Fig. 2) is that the additional pairs of facial shades are already in a different tonal state, which is necessary for their harmonious combination. The transition from yellow to white and from red to black is carried out diagonally. Harmonious chords of contrasting color nuances are also found on the diagonal axes.

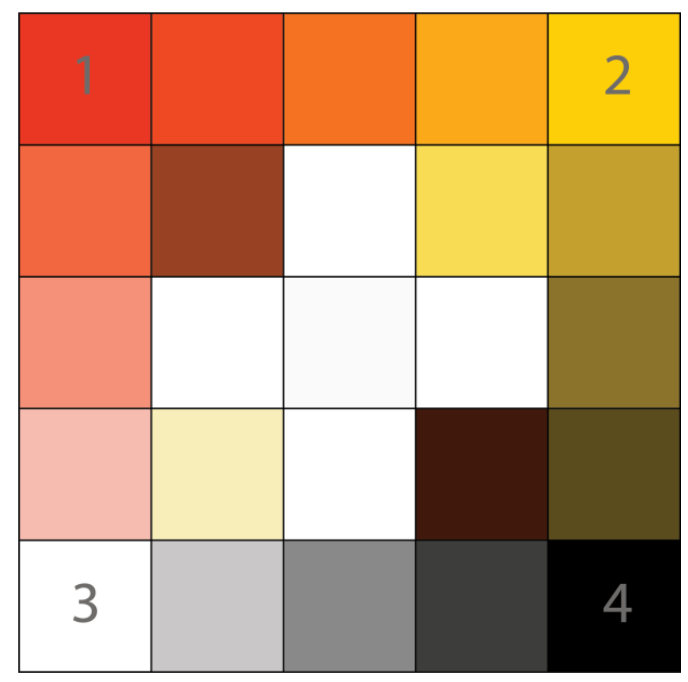

Fig. 2. Scheme color square. (Developed by the authors).

We know four primary colors and intermediate tones. Due to the preserved preparatory drawings of the time, it is known that the contour lines were drawn in brown paint. The names of the colors were given to their places of production. Pliny gives us information about this: the clean areas drew by the "Ocher of Attica" and the shadows from the "Ocher of Lydia." As a white, they used Melo's pigment, yellow - "Ocher Attica," red - "Ocher Sinop and Pontius." Black - "atrament." All other tones are obtained by mixing these four primary colors. Now we need to restore the color of work. Among other things, this is a more straightforward task of all. Most likely, it was some burned bone. Due to the technology of the iconography of Byzantium, we have an idea about ancient Greeks using layers of paint and types of mixtures. And in the end, we can intuitively understand how this works. This is because certain artistic rules justify the use of light and shadow, depending on the lighting and posture of the model:

1. After the drawing was completed (Fig. 1a), Apelles had to draw the silhouette of the figure in an olive tone (Fig. 1b). The reason for this layer is to create a mid-tone that will allow you to simulate the midtones between light and shadows. The hair is colored brown (Fig. 1b).

2. The next stage is to cover the surface of the body with a skin tone that is slightly lighter than the previous layer. In the case of hair, it is lighter than brown (Fig. 1c).

3. With the same body color, but a little brighter, more lighted places stand out. This procedure is repeated three times, with the less and less occupied surface. And at the end of everything, small strokes of almost white color are placed (Fig. 1c).

4. Then reddish places of the body are painted with transparent red ocher, for example, on the cheeks. Next, the work is connected with a very transparent layer of yellow ocher, and the shadow with a dark brown transparent (Fig. 1c).

Unfortunately, historians of the past did not leave us any mention of the size and proportion of work. We can only conclude based on secondary information. For example, we have a mention by Pliny the Elder of another work - "The Sacrifice of the Bulls" by Pavsias from Sicion. It turns out that this painting was placed in the portico of the temple. Well, how can this information help us? By the way, if this portico was on the porch of the temple, then the work was quite large. We can assume that the picture of Apelles was of considerable size. Most likely - the height of a person. This hypothesis is supported by many stories commented on by the Roman historians themselves. Several epigrams describe the excellent quality of Greek painting. For example, when pigeons came down to eat a painted still life, or a dog recognized its owner, painted in a portrait. It isn't very easy to assume that a dog recognizes a person on a completely different scale than usual. This means that the size of the portrait was close to natural. We have the words of a historiographer, how charming Aphrodite Apelles was. In the world of art, there is an ancient aesthetic rule, according to which a human figure cannot be full-scale, must be slightly larger or smaller. Thus, the Greeks had to follow this. We obtain a working height of $1.70-1.60 \mathrm{~m}$. Following the words of Pliny at that moment, the Goddess emerges 
from the sea. Logically, the format for the standing figure will be vertical. Currently, two techniques of ancient Greek painting are known - tempera and encaustic painting. The most important works that the Greek masters created were made in a more advanced and significant technique - encaustic painting. Unfortunately, historians of the past did not leave us any mention of the size and proportion of work.

We can only conclude based on secondary information. We can assume that the picture of Apelles was of considerable size. Most likely - the height of a person. This hypothesis is supported by many stories commented on by the Roman historians themselves. We have the words of a historiographer, how charming Aphrodite Apelles was. In the world of art, there is an ancient aesthetic rule, according to which a human figure cannot be full-scale, must be slightly larger or smaller. Thus, the Greeks had to follow this. We obtain a working height of $1.70-1.60 \mathrm{~m}$. Following the words of Pliny at that moment, the Goddess emerges from the sea. Logically, the format for the standing figure will be vertical. Currently, two techniques of ancient Greek painting are known - tempera and encaustic painting. The most important works that the Greek masters created were made in a more advanced and significant technique - encaustic painting. This is due to the form of application. For this reason, the Greeks developed a particular technique that solved this problem for both techniques. Thus, we have almost all parts of this puzzle.

Coclusions. Established the basic necessary items for the restoration of the lost pictorial works of art. The primary reconstruction algorithm is described: the drawing, composition, and methodology of the work of ancient Greek art. Systematized Hellenistic Greek colors according to the scheme "Colored Square". A sequence has been developed for the reconstruction of the leading figure of Apelles' work: "Aphrodite Anadiomena." Prospects for future publications. The continuation of the current topic is planned to complete the reconstruction of the painting composition "Aphrodite Anadiomena."

\section{תimepamypa}

1. Чистякова Н. А. Греческая эпиграмма: монография. Санкт-Питербург: Наука, 1993. 449 с. 1988. 192 c.

2. Неверов О. Я. Античные камеи в собрании Эрмитажа: монографрия. Санкт-Питербург: Искусство, $942 \mathrm{c}$.

3. Плиний Старший. Естествознание. Об искусстве / примеч. Г. А. Тароняна. Москва: Ладомир, 1994.

4. Элиан. Пестрые рассказы / примеч. С. В. Поляковой. Москва: Изд. Академии Наук СССР, 1963. 189 с.

5. Keuls Eva. Skiagraphia Once Again American. Journal of Archaeology /1975. Vol. 79, No. 1. P. 1-16.

6. Иттен И. Искусство цвета: монография. Москва: Изд. Д. Аронов, 2004. 53 с.

7. Киплик Д. И. Техника живописи: монография. Москва: Изд. В. Шевчук, 2002. 536 с.

\section{References}

1. Chistyakova N. A. (1993). Greek epigram. Sanct Piterburg. Nauka [in Russian].

2. Neverov O. Y. (1988). Antique Cameos in the Hermitage Collection. Sanct Piterburg. Iskusstvo [in Russian].

3. Pliniy Starshiy. (1994). Natural science. About art. G. A. Taronyan. (Eds.). Moskva. Ladomir [in Russian].

4. Elian. (1963). Variegated stories. S. V. Polyakova (Eds.). Moskva. Izd. Akademii Nauk SSSR [in Russian].

5. Keuls Eva (1975). Skiagraphia Once Again. Journal of Archaeology [in English].

6. Itten I. (2004). Art of color. Moskva. Izd. D. Aronov [in Russian].

7. Kiplik D. I. (2002). Painting technique. Moskva. Izd. V. Shevchuk [in Russian].

Стаття надійшла до редакції 27.07.2019 р. 